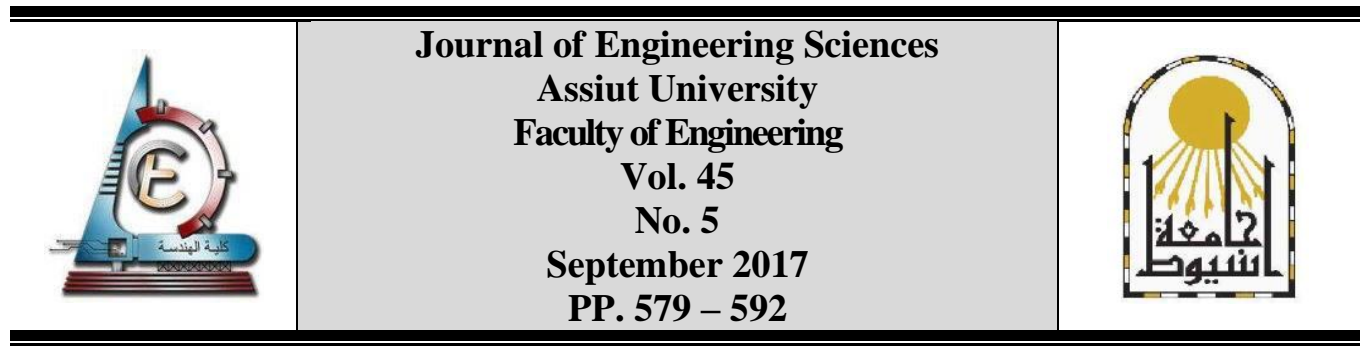

\title{
STRENGTHENING OF SKYLIGHT COLUMNS OF BUILDINGS TO RESIST EARTHQUAKE USING BRACING
}

\author{
Aly Gamal Aly Abdel- Shafy ${ }^{1}$, Mohamed Mahmoud Ahmed ${ }^{2}$ \\ Asmaa Ahmed Thabet Omer *, 3 \\ ${ }^{1,2}$ Civil Engineering, Faculty of Engineering, Assiut University \\ ${ }^{3}$ Master student, Civil Engineer
}

Received 5 July 2017; Accepted 6 August 2017

\begin{abstract}
This research presents an investigation through a numerical study on the effect of bracing for skylights columns in multi story building. Variable parameters were taken into consideration such as number of bracing, stiffness of columns, beam cross -section. Base shear force of the building, top displacement, story drift as well as bending moment and shear force on columns were estimated under seismic loads, and the obtained results were studied and discussed. In this case of study, number of stories was taken fifteen, total plan dimensions was $20 \times 35 \mathrm{~m}^{2}$ with $(4 \times 5) \mathrm{m}$ bay dimensions. The commercial computer program ETABS was used in the analysis. The results showed that skylight columns bracing has a significant impact on base shear force, top displacements, story drift as well as bending moment and shear force on columns for the different parameters taken into consideration.
\end{abstract}

Keywords: Seismic designs, strengthening of multistory building, retrofit systems, strength and stiffness.

\section{Introduction}

Occurrences of recent earthquakes in different parts of the world and the resulting losses, especially human lives, have highlighted the structural inadequacy of buildings to carry seismic loads. There is an urgent need for strengthening existing buildings in terms of seismic performance. Since October 1992, a set of Egyptian codes have been released to prevent building collapse and control major damages of structural elements.

These buildings were not well designed to resist seismic loading [9].

Braced frames reduce lateral displacement, as well as the bending moment in columns, they are economical, easily erected and have the design flexibility to create the strength and stiffness required [15]. It helps make buildings sturdier and more likely to withstand lateral forces. Bracing can be used in strengthening most all types of concrete, masonry or steel-framed buildings. Moreover it can be also used when a tall building is subjected to lateral or torsional deflections under the action of fluctuating wind loads and the

* Corresponding author.

E- mail address: asmaahmedomer@yahoo.com 
earthquake. Bracing is considered as available dead load of structure that can be mobilized to resist overturning uplift [6]. However, this method of strengthening was usually used in steel construction, and rarely in concrete structures. Moreover, the bracing cross-section was mostly from steel. Few previous works on using bracing in concrete structures are available. Therefore this study was made to investigate the effect of strengthening for RC buildings using bracing with reinforced concrete cross-section.

The purpose of strengthening methods is to ensure that the displacement demand of a building is to be kept below its displacement capacity [14]. There are many retrofit systems developed for RC buildings. One of these methods for the strengthening of buildings is system based strengthening [12]. In the system based strengthening methods, a structural system is modified by adding members such as reinforced concrete shear walls, [10] infill shear walls, external shear walls, adding walls to existing columns, ,encasing columns and steel bracing [8],[11]. Infill Strengthening, mainly improves the strength and stiffness characteristics of the system [2]. The seismic Performances of R.C building with and Without Influence of Steel Bracing were studied by Naveen et al [13]. It was found that increasing number of storey with bracings increase the stiffness and control drifts and displacement. Results showed that the reinforced concrete building with steel bracing system performs better than any other normal building under severe earthquake zones. While the bracings decrease the bending moments and shear forces in columns, they increase the axial compression in the columns to which they are connected. The bracings are provided with the steel members and are diagonally connected in the form of $\mathrm{X}$ at the location [7]. There is a significant reduction in the seismic vulnerability of the building after retrofitting of building with steel bracing. Seismic Retrofit of Reinforced Concrete Frame Buildings with Hysteretic Bracing Systems, controls the maximum interstorey drifts, imposes a maximum top displacement as function of the seismic demand and, if needed, regularizes the stiffness and strength of the building along its elevation [1].

The purpose of this study is to try to clarify the effect of strengthening skylights columns of RC buildings for earthquake resistance using R.C bracing. Fifteen story reinforced concrete building was designed under seismic loads, then the obtained results were analysed and discussed. The equivalent static load has been used in this study .The main objective is to assess the total base shear, top displacements and drift between stories.

\section{Building description and design}

The studied case is a fifteen stories reinforced concrete building. The plan dimension is 20.0 meter by 35.0 meter with a typical bay $4.0 \times 5.0 \mathrm{~m}$. The configurations of the building plan and elevation views are shown in Fig (1) to (4). The total height of the building from the ground level is $46 \mathrm{~m}$, the typical story height is $3.0 \mathrm{~m}$ except the first story, which has a height of $4 \mathrm{~m}$. The dimensions of the columns are $40 \mathrm{~cm} \times 160 \mathrm{~cm}$ with $20 \phi 20$ longitudinal reinforcement and $6 \phi 8 / \mathrm{m}^{\prime}$ as stirrups. The building structural elements have been first analysed and designed according to Egyptian code of practice (ECP 203-2007)[5]. The materials used in the design are C300 for concrete and St52 for steel (characteristic yield strength for steel of $3600 \mathrm{~kg} / \mathrm{cm}^{2}$ ). Rectangular columns were used with different plan orientation to represent the change in lateral rigidity. Also, a different beams and slab cross-sections were used to represent the rigid diaphragm effect. These sections have been checked under seismic actions by using the Egyptian code for load and forces (ECLF 2012) [4]. The model is assumed to be a residential building with maximum live load of 
$250 \mathrm{~kg} / \mathrm{m}^{2}$. ETABS 2015 analysis program automatically estimates the own weight of the structural elements and include it in the elastic and inelastic analysis [3]. Because of symmetry in both directions, the torsional effect has not taken into consideration at this case of modelling.

\section{Finite element model}

A three-dimensional mathematical model of the physical structure will be used to represent the spatial distribution of the mass and stiffness of the structure. A multi-storey building model of a hypothetical reinforced concrete building has been analyzed using ETABS 2015 structural analysis software package. The building is modeled as 3D building structure using building elements for columns, longitudinal beams and transverse beams and shell element for slabs with rigid floor diaphragms to distribute uniformly the lateral loads on the vertical elements.

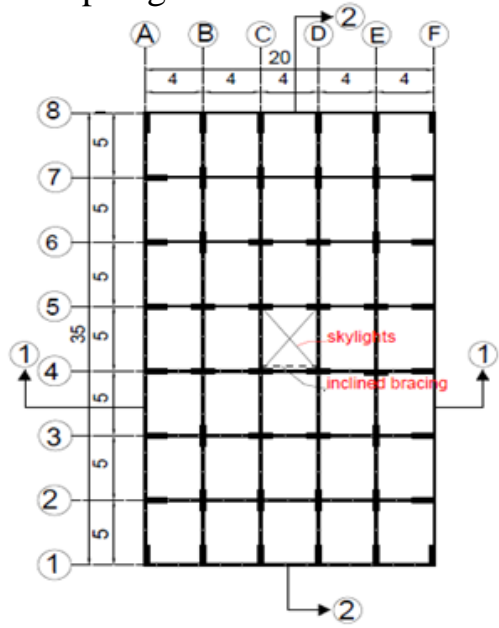

Typical Floor plan for braced cases in one $\mathrm{x}$-plane

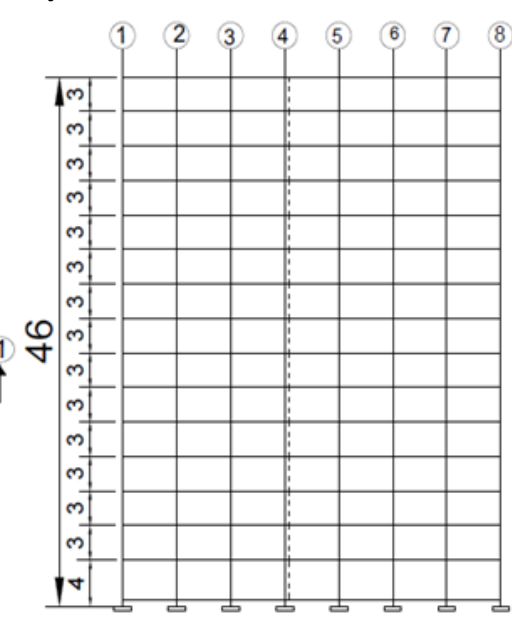

Sec (2-2) $100 \%$ plane bracing

Fig. 1. The investigated building.

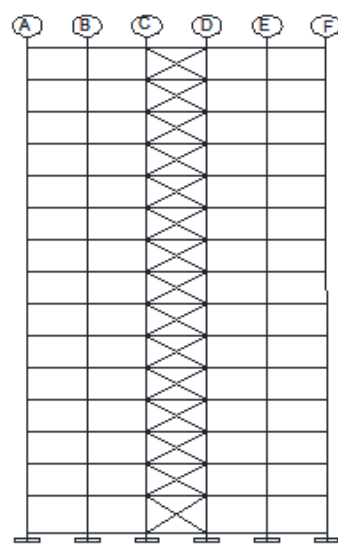

a) $100 \%$ bracing

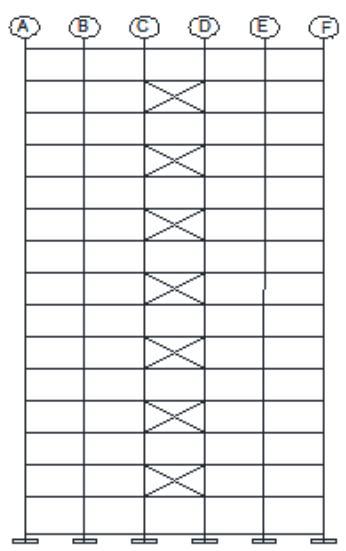

b) $50 \%$ bracing

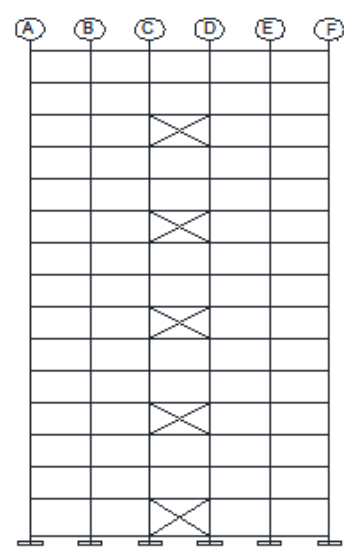

c) $33 \%$ bracing

Fig. 2. SEC (1-1) [the shape of plan bracing (x-inclined) used for strengthening in building]. 


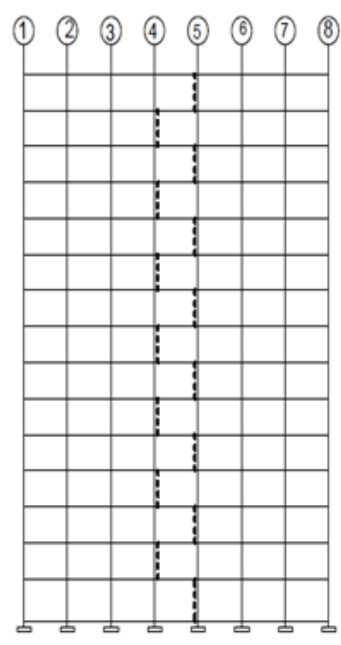

a) $100 \%$ bracing

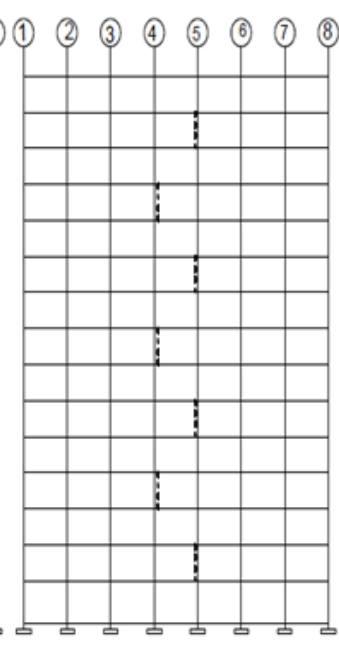

b) $50 \%$ bracing

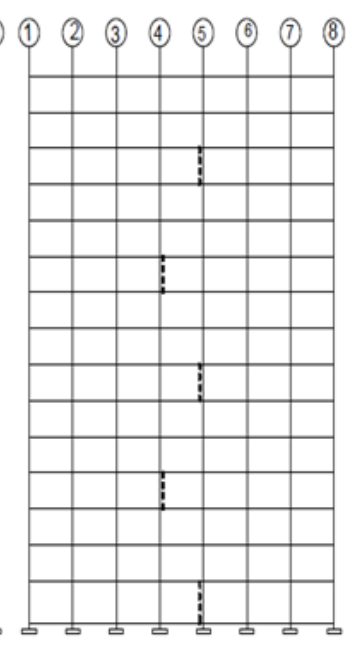

c) $33 \%$ bracing

Fig. 3. SEC (2-2) [the shape of staggered bay bracing (x-inclined) used for strengthening in building].

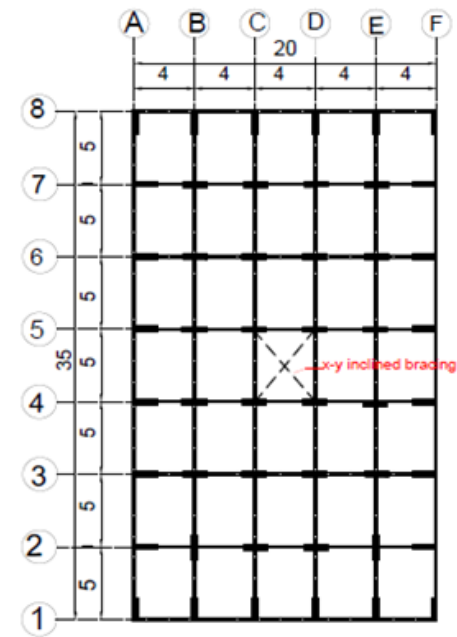

a) Space bracing ( $x-y$ inclined bracing)

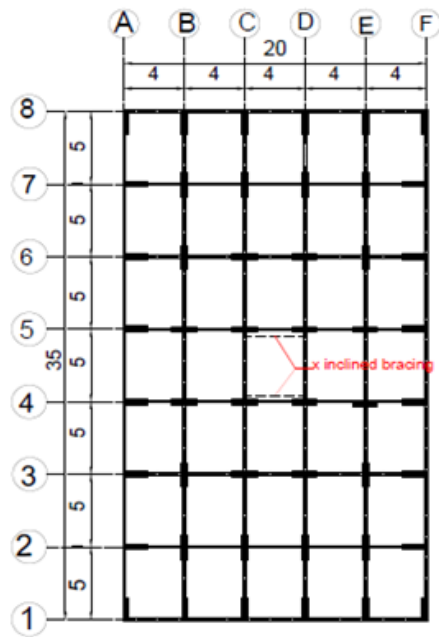

b) Staggered bay bracing ( $x$ inclined bracing)

Fig. 4. The plan of bracing in building.

\section{Seismic analysis procedures}

The equivalent static lateral force method (ESL) has been used. According to ECP-201 (2012), the seismic base shear force, $F_{b}$, for each horizontal direction in which the building is analyzed, shall be determined using the following expression:

$$
F_{b}=S_{d}\left(T_{1}\right) \times \lambda \times W / g
$$

Where: $S_{d}\left(T_{1}\right)$ is the ordinate of the design spectrum at period $T_{1} ; T_{1}$ is the fundamental period of vibration of the building for lateral motion in the direction considered; $W$ is the total weight of the building, above the foundation level; $g$ is the gravity acceleration ; $\lambda$ is the effective modal mass correction factor, the value of which is equal to: $\lambda=0.85$ for $T \leq 2 T_{\mathrm{C}}$, and $n>2$ stories, $\lambda=1.0$ for $T \geq 2 T_{\mathrm{C}}$, where $n$ number of stories; $T_{c}$ is the upper limit of the period of the constant spectral acceleration branch as shown in Fig (5). 
The value of Fundamental period of vibration of the building in the direction of the analysis is determined using the following expression:-

$$
T=C_{t} \times H^{3 / 4}
$$

Where $C_{t}$ is a factor determined according to the structural system and building material and was taken equal to $0.050 ; H$ is the height of the building $(m)$; from the foundation or from the top of a rigid basement. The ordinate of the design spectrum, $S_{d}\left(T_{1}\right)$, can be determinate from:-

$$
s_{d}(T)=\frac{2.5}{R} \times a_{g} \times \gamma \times S\left[\frac{T_{c}}{T}\right] \geq[0.2] \times a_{g} \times \gamma
$$

Where $a_{g}$ is the design ground acceleration for the reference return period; $S$ is the soil factor. $\gamma$ : Importance factor (for ordinary buildings $\gamma=1$, as it was taken in the present study). The seismic zone considered in this study is zone 3. $\boldsymbol{R}$ is the reduction factor according the statical system of the structure $(R=5)$. $\eta$ :Design damping factor for elastic response spectrum (In case of reinforced concrete $\boldsymbol{\eta}=1$,

$\mathbf{T}_{\mathbf{B}}, \mathbf{T}_{\mathbf{C}}$ : Constant value limits of elastic response spectrum

$\mathbf{T}_{\mathbf{D}}$ : limited value for the starting of fixed spectrum movement.

In the present study, the Elastic response spectrum curve type one is considered (this type is used for all republic areas) and soil classification is assumed to be medium soil class "C"

$$
\text { So, } \mathbf{S}=1.5, \mathbf{T}_{\mathbf{B}}=0.1, \mathbf{T}_{\mathbf{C}}=0.25, \mathbf{T}_{\mathbf{D}}=1.2
$$

It should be noted that, ECLF 2012 recommends that in the application of the ESFM method, the building should meet the criteria for regularity in both plan and elevation, and with calculated structural period $T$ not greater than $2 \mathrm{sec}$ or $4 T c$ (1 sec for the selected soil class (class " $C$ "). The total base shear, $F_{b}$, shall be determined by applying horizontal forces $F_{i}$ to each story mass $m_{i}$ and shall be distributed as follows:-

$$
F_{i}=\left[\frac{z_{i} \times w_{i}}{\sum_{\tilde{i}=1}^{n} z_{j} \times w_{j}}\right] \times F_{b}
$$

Where $F_{i}$ is the horizontal force acting on story $i ; F_{b}$ is the seismic base shear force (Eq. [1] ); $z_{i}, z_{j}$ are the heights of the masses $m_{i}, m_{j}$ above the foundation level respectively; $W_{i}$, $W_{j}$ are the weights of masses $m_{i}, m_{j} ; n$ is the number of stories above foundation level.

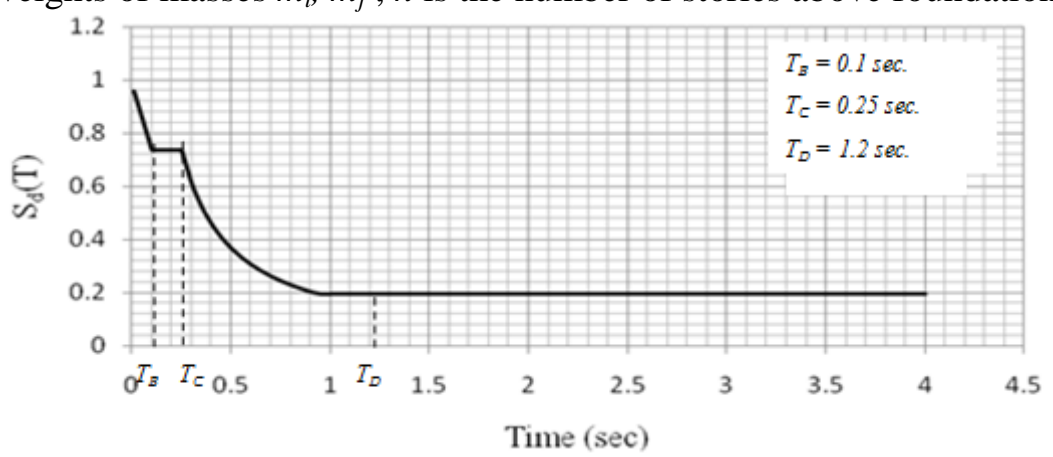

Fig. 5. Design response spectrum for all regions of Egypt except coastal areas. 


\section{Results and discussions}

Twenty one different models, 15-story building, given in 5 groups A,B,C,D,E, in table land table 2 , have been studied to evaluate the effect of the bracing on the value of the induced base shear and the resulted displacement as well as story drift. In all groups the beam and bracing cross-section are constant $(25 \times 50)$, columns cross-section is constant $(40 \times 160)$, thickness of slab is constant $(15 \mathrm{~cm})$ and area of skylights is constant $(4 \times 5)$, except group $E$ the beam cross-section is variable and the area of skylight is $(4 \times 15)$.

\subsection{Effect of the ratio of the braced stories}

In groups $\mathrm{A}, \mathrm{B}, \mathrm{C}$, the main parameter was the ratio of the braced stories for different cases. The obtained results showed that, with increasing the percentage of braced stories, the ratio $(\delta / \delta$ all) and maximum story drift decreased and this is shown in Fig (6). Fig (7) shows that, when using staggered bay bracing, on two axes (Model B 4, 5, 6) the ratio of $(\delta / \delta$ all $)$ as well as story drift decreased compared with that of plane bracing. This decrease increased with increasing the bracing ratio. The percentage of story drift will decrease by $36.9 \%$ when using staggered bay bracing $200 \%$ compared with the model without bracing. The using of staggered bay bracing $200 \%$ seems to have small effect compared with the using of staggered bay bracing $100 \%$. The percentage of story drift will decrease by $3.4 \%$ when using staggered bay bracing $200 \%$ compared with the model using staggered bay bracing $100 \%$. The maximum efficiency occurred when using staggered bay bracing $100 \%$ as shown in Model B6. The percentage of story drift decreased by $19.4 \%$ when increasing in the ratio of ( $\mathrm{x}$-inclined) plan bracing, but when using ( $\mathrm{x}-\mathrm{y}$ inclined) space bracing, story drift decreased by $23.3 \%$ compared with the model without bracing. The percentage of decrease in maximum story drift will increase with increasing in the number of bracing stories. Maximum percentage of decrease in maximum story drift will get it from using staggered bay bracing $200 \%$ in area of skylights. From Fig (8) shows that, with increasing in the number of braced stories in two axis $\mathrm{x}$ - bay direction, the maximum story drift and maximum displacement decreased. It shall be noted that, when using staggered bay bracing $100 \%$ with increasing in the number of braced stories, the maximum story drift and maximum displacement will be decreased. Fig (9) shows that, with increasing in the number of braced stories in one $\mathrm{x}$ - bay direction, the maximum story drift and maximum displacement decreased. From Fig (10) it is clear that the effect of space bracing, (three dimensional) is slightly more effective than the plane bracing, especially in the upper stories of the building. Fig (11) shows that, the using of staggered on two bay bracing decreased both the ratio $(\delta / \delta$ all) and the ratio ( $\delta \mathrm{r} / \delta \mathrm{r}$ all), It can change the unsafe values of the ratio ( $\delta / \delta$ all) and the ratio ( $\delta \mathrm{r} / \delta \mathrm{r}$ all) to be within the allowed limit. 
Table 1.

Building with bracing for various columns rigidity groups.

\begin{tabular}{|c|c|c|c|c|c|c|c|c|c|c|c|c|}
\hline $\begin{array}{l}\stackrel{0}{二} \\
\stackrel{0}{0} \\
\dot{0}\end{array}$ & $\begin{array}{l}\frac{n}{0} \\
\frac{0}{0} \\
\Sigma\end{array}$ & $=$ & $\vec{a}$ & 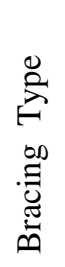 & 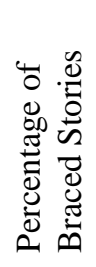 & $\underbrace{\text { हृ }}_{\infty}$ & $\frac{0^{\overline{7}}}{\infty}$ & ப் छี & $\frac{\vec{c}}{\bar{E}}$ & 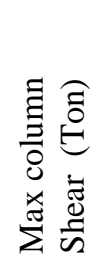 & 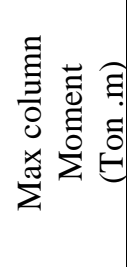 & 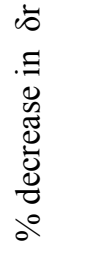 \\
\hline \multirow{4}{*}{ A } & $\mathrm{M}_{\mathrm{A} 0}$ & 24 & 24 & --- & --- & 11.8 & 1.28 & 1.0542 & 1.230 & 17.36 & 142.46 & --- \\
\hline & $\mathrm{M}_{\mathrm{A} 1}$ & 24 & 24 & $\mathrm{P}$ & $33 \%$ & 10.8 & 1.17 & 0.9537 & 1.113 & 17.36 & 115.75 & $9.5 \%$ \\
\hline & $\mathrm{M}_{\mathrm{A} 2}$ & 24 & 24 & $\mathrm{P}$ & $50 \%$ & 10.7 & 1.16 & 0.9297 & 1.085 & 17.3 & 118.1 & $11.8 \%$ \\
\hline & $\mathrm{M}_{\mathrm{A} 3}$ & 24 & 24 & $\mathrm{P}$ & $100 \%$ & 10.5 & 1.14 & 0.9123 & 1.065 & 14.52 & 110.6 & $13.5 \%$ \\
\hline \multirow{8}{*}{ B } & $\mathrm{M}_{\mathrm{B} 0}$ & 30 & 18 & 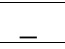 & & 10.74 & 1.17 & 0.9504 & 1.109 & 15.09 & 121.7 & --- \\
\hline & $\mathrm{M}_{\mathrm{B} 1}$ & 30 & 18 & $\mathrm{P}$ & $33 \%$ & 9.8 & 1.07 & 0.855 & 0.998 & 15.6 & 98.13 & $10.0 \%$ \\
\hline & $\mathrm{M}_{\mathrm{B} 2}$ & 30 & 18 & $\mathrm{P}$ & $50 \%$ & 9.7 & 1.05 & 0.8397 & 0.980 & 15.7 & 99.6 & $11.6 \%$ \\
\hline & $\mathrm{M}_{\mathrm{B} 3}$ & 30 & 18 & $\mathrm{P}$ & $100 \%$ & 9.6 & 1.04 & 0.825 & 0.963 & 12.42 & 93.12 & $13.2 \%$ \\
\hline & $\mathrm{M}_{\mathrm{B} 4}$ & 30 & 18 & SP & $33 \%$ & 8.55 & 0.93 & 0.7554 & 0.881 & 15.32 & 94.64 & $20.5 \%$ \\
\hline & $\mathrm{M}_{\mathrm{B} 5}$ & 30 & 18 & SP & $50 \%$ & 8.15 & 0.886 & 0.69 & 0.805 & 15.37 & 96.89 & $27.4 \%$ \\
\hline & $\mathrm{M}_{\mathrm{B} 6}$ & 30 & 18 & SP & $100 \%$ & 7.7 & 0.84 & 0.6321 & 0.738 & 11.95 & 84.32 & $33.5 \%$ \\
\hline & $\mathrm{M}_{\mathrm{B} 7}$ & 30 & 18 & SP & $200 \%$ & 7.4 & 0.81 & 0.5994 & 0.699 & 11.1 & 77.36 & $36.9 \%$ \\
\hline \multirow{4}{*}{$\mathrm{C}$} & $\mathrm{M}_{\mathrm{C} 0}$ & 34 & 14 & --- & --- & 10.26 & 1.12 & 0.9072 & 1.059 & 14.29 & 112.83 & --- \\
\hline & $\mathrm{M}_{\mathrm{C} 1}$ & 34 & 14 & $\mathrm{P}$ & $33 \%$ & 8.8 & 0.96 & 0.7572 & 0.884 & 14.48 & 90.24 & $16.5 \%$ \\
\hline & $\mathrm{M}_{\mathrm{C} 2}$ & 34 & 14 & $\mathrm{P}$ & $50 \%$ & 8.7 & 0.95 & 0.7437 & 0.868 & 14.57 & 91.7 & $18.0 \%$ \\
\hline & $\mathrm{M}_{\mathrm{C} 3}$ & 34 & 14 & $\mathrm{P}$ & $100 \%$ & 8.6 & 0.94 & 0.7308 & 0.853 & 11.4 & 86.54 & $19.4 \%$ \\
\hline D & $\mathrm{M}_{\mathrm{D} 1}$ & 34 & 14 & $S$ & $100 \%$ & 8.2 & 0.89 & 0.696 & 0.812 & 12.01 & 90.55 & $23.3 \%$ \\
\hline
\end{tabular}

\section{Where that:-}

$\mathbf{n}_{\mathbf{x}}, \mathbf{n}_{\mathbf{y}}$ : Number of columns oriented in $\mathrm{x}$ and y direction respectively .

$\boldsymbol{\delta}$ : Maximum top displacement for the building .

$\boldsymbol{\delta} \mathbf{r}$ : Maximum story drift for building.

$\boldsymbol{\delta}_{\text {all }}$ : The maximum safe displacement for building given by the code $=\mathrm{H} / 500=9.2$

$\boldsymbol{\delta} \mathbf{r}_{\text {all }}$ : The maximum safe story drift for building given by the code.

$\mathbf{H}$ : The building height above the foundation level .

Percentage of Braced Stories (-): no bracing in building.

$(\mathbf{3 3 \%})$ : bracing each three stories in $\mathrm{x}$-bay $4-4$ of the skylight.

$\mathbf{5 0 \%}$ ): bracing each two stories in $\mathrm{x}$-bay 4-4 of the skylight.

(100\%): bracing in all stories in $\mathrm{x}$-bay $4-4$ of the skylight.

P: plane bracing i.e. inclined bracing in $\mathrm{x}$-direction.

$\mathbf{S}$ : space bracing i.e. inclined bracing in $\mathrm{x}-\mathrm{y}$ direction.

SP: staggered bay bracing in $\mathrm{x}$-bay axis $4-4 \& 5-5$ of the skylight. 

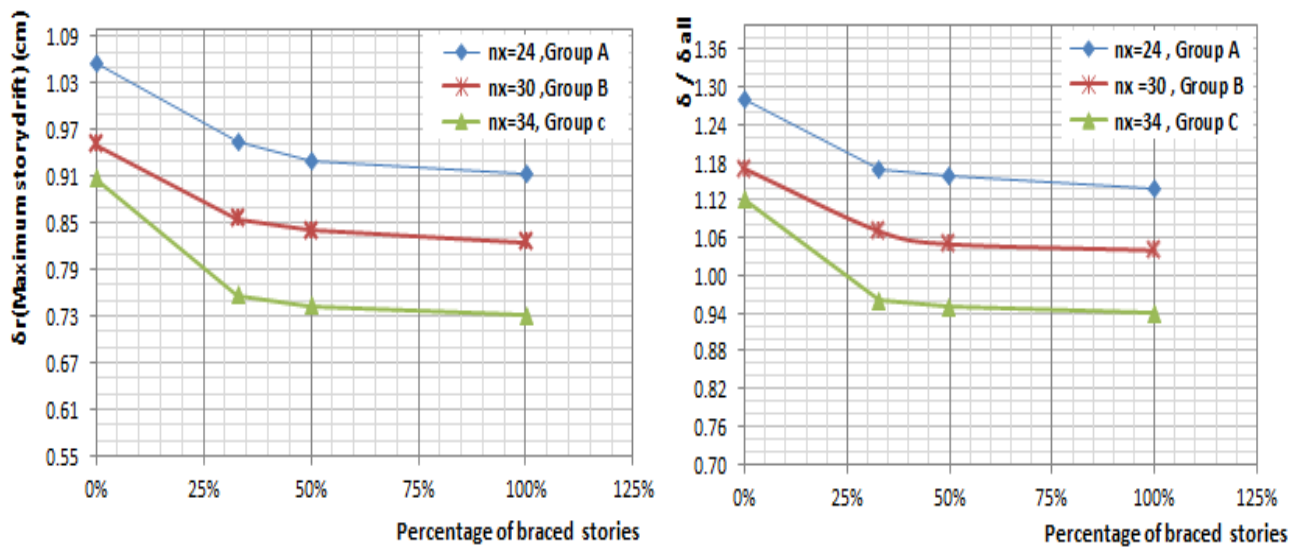

Fig. 6. Effect of the percentage of braced stories on $\left(\delta / \delta_{\text {all }}\right)$ and maximum story $\operatorname{drift}(\delta \mathrm{r})$.

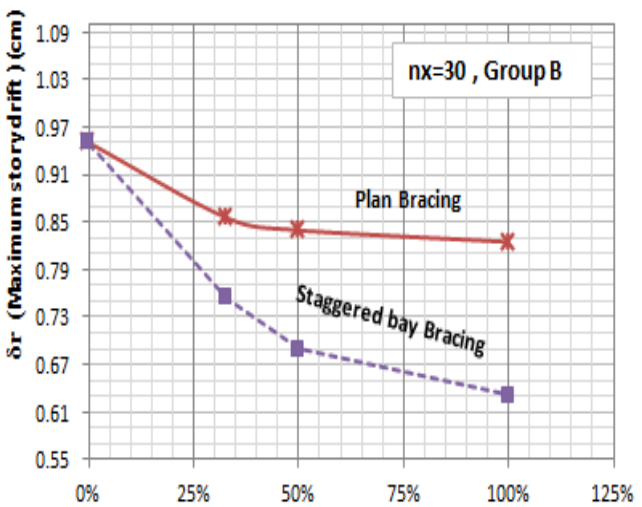

Percentage of braced stories

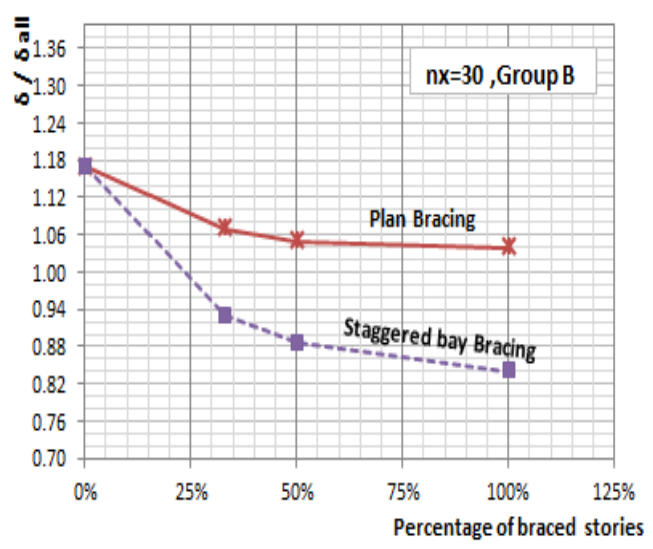

Fig. 7. Effect of the staggered bay bracing (x-inclined) on $\left(\delta / \delta_{\text {all }}\right)$ and maximum story $\operatorname{drift}(\delta \mathrm{r})$.
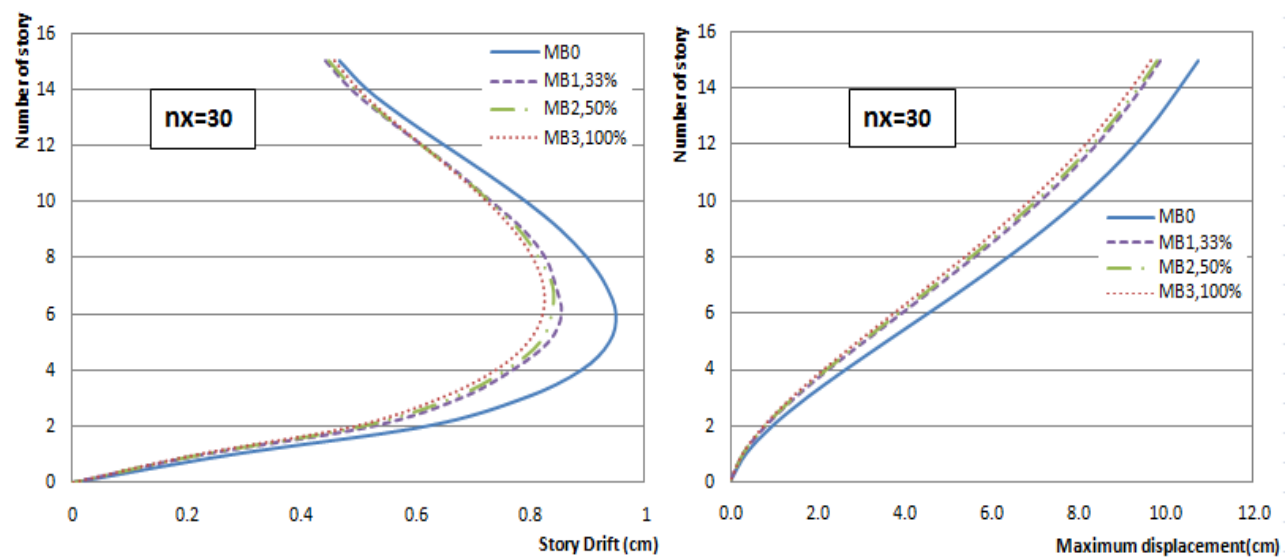

Fig. 8. Effect of staggered bay bracing (x-inclined) on top displacements and story drift models. 
Asmaa Ahmed Thabet Omer et al., Strengthening of skylight columns of buildings to resist ...........
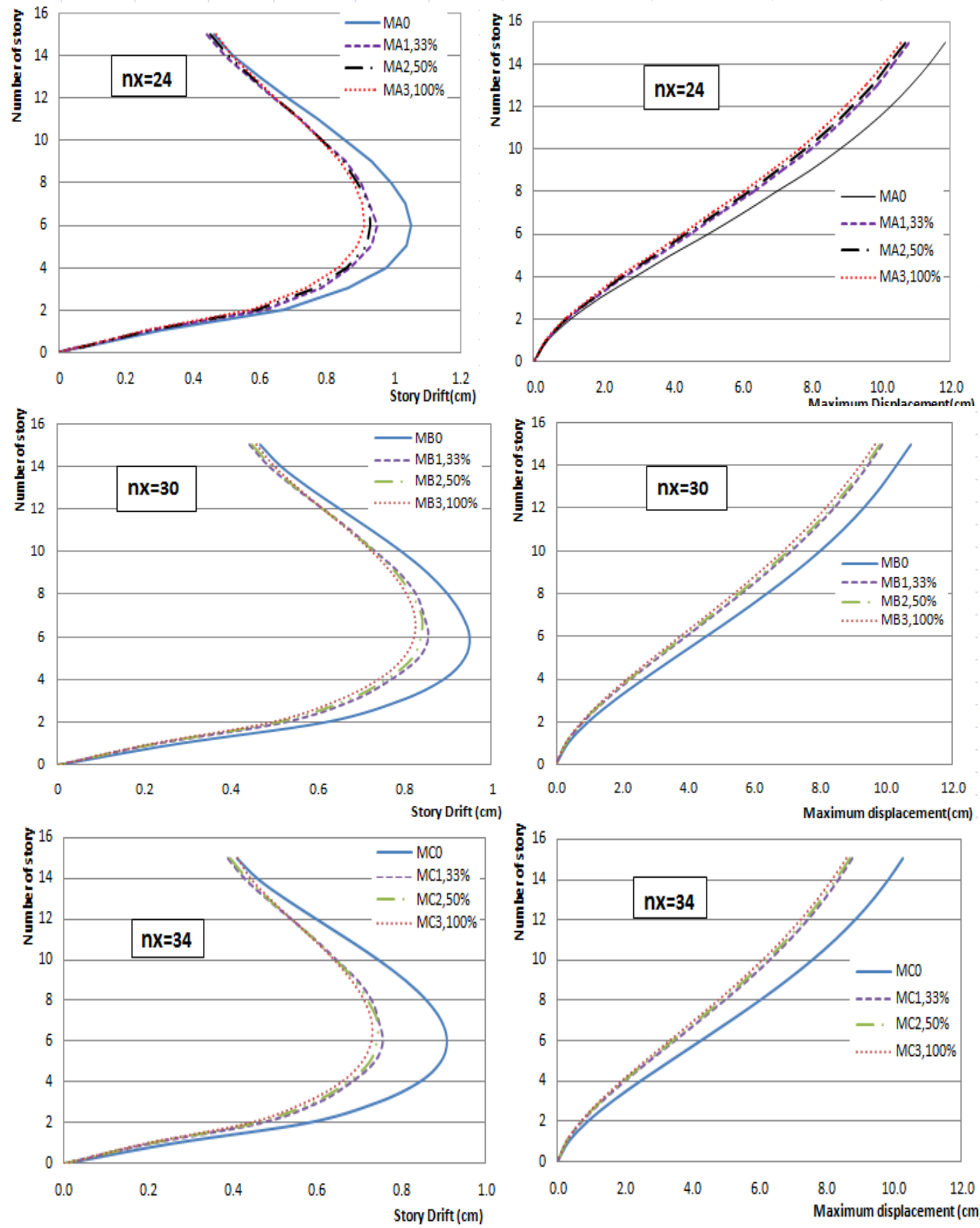

Fig. 9. Effect of plane bracing (x-inclined) on top displacements and story drift models 
JES, Assiut University, Faculty of Engineering, Vol. 45, No. 5, September 2017, pp.579-592
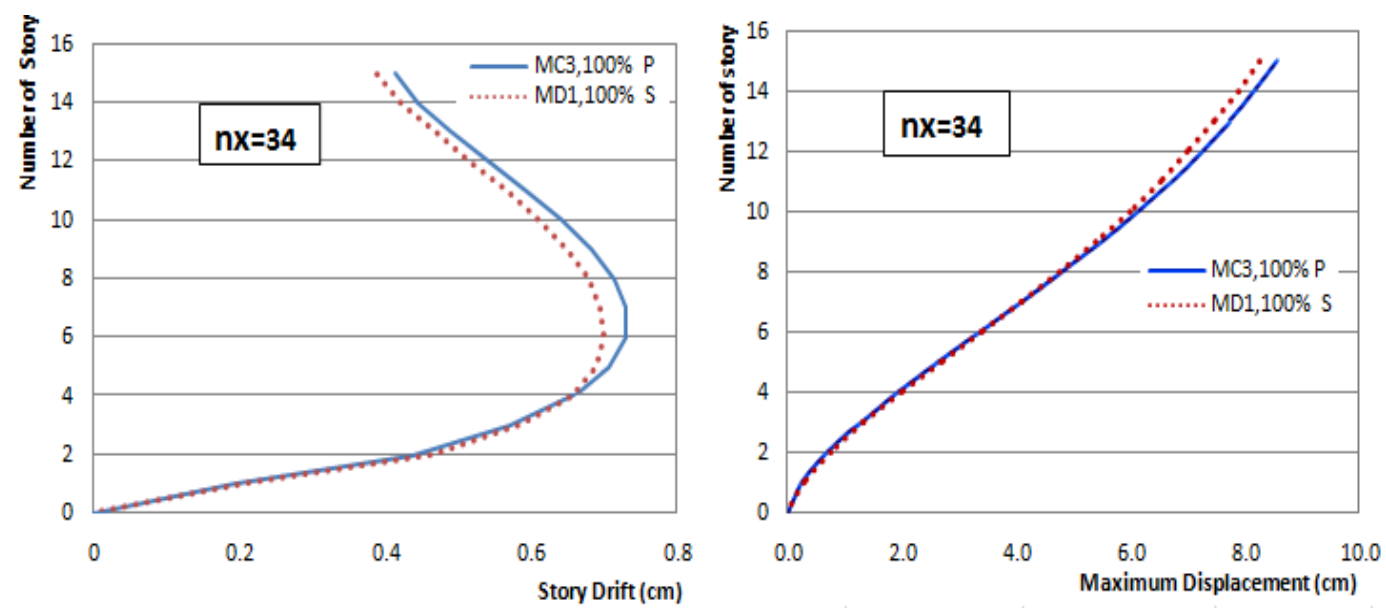

Fig. 10.Effect of space bracing(x-y inclined) of full bracing on top displacement and story drift models
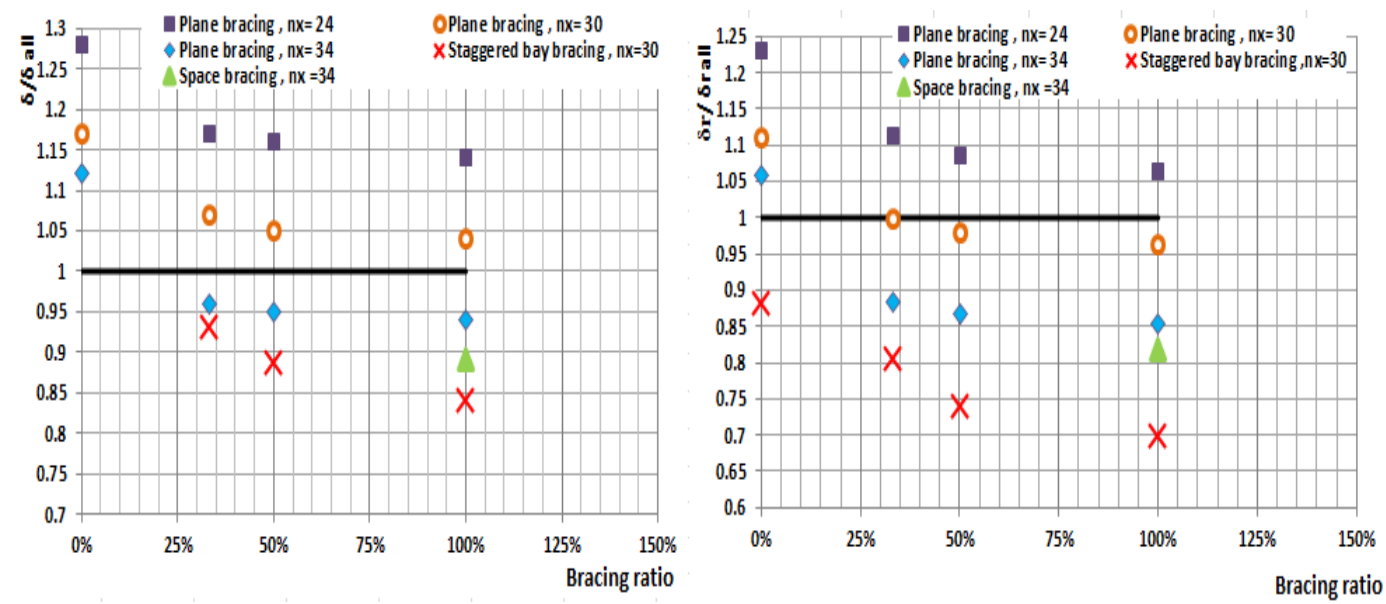

Fig. 11. Effect of bracing type on $\left(\delta / \delta_{\text {all }}\right)$ and $\left(\delta \mathrm{r} / \delta \mathrm{r}_{\text {all }}\right)$.

\subsection{Effect of Bracing for various column rigidities}

In all models the total number of columns was 48 . In group $A\left(M_{A 1}, M_{A 2}, M_{A 3}\right)$ with variable $\mathrm{x}$ bay bracing ratio, the number of columns oriented in $\mathrm{x}$ direction was 24 . In group $\mathrm{B}\left(\mathrm{M}_{\mathrm{B} 1}, \mathrm{M}_{\mathrm{B} 2}, \mathrm{M}_{\mathrm{B} 3}\right)$ with variable $\mathrm{x}$ bay bracing ratio, the number of columns oriented in $\mathrm{x}$ direction was 30 . In groups $\mathrm{C}\left(\mathrm{M}_{\mathrm{C} 1}, \mathrm{M}_{\mathrm{C} 2}, \mathrm{M}_{\mathrm{C} 3}\right), \mathrm{D}\left(\mathrm{M}_{\mathrm{D} 1}\right)$ with variable $\mathrm{x}$ bay bracing ratio, the number of columns oriented in x direction was 34 . Model $\mathbf{M}_{\mathbf{A 0},}, \mathbf{M}_{\mathbf{B} \mathbf{0}}, \mathbf{M}_{\mathbf{C 0} \text {, }}$ were taken without any bracing. In $\mathbf{M}_{\mathbf{D} 1}$ had space bracing with inclined in $\mathrm{x}-\mathrm{y}$ plane to the horizontal in all stories. The obtained test results are included in Table 1. From this table it can be seen that the presence of bracing in general reduces each of the maximum induced shear, maximum moment, the top displacement and the maximum story drift. The effect of bracing seems to be increased with increasing the stiffness of columns in the load direction Fig (12). The total base shear and bending moment for columns decreased when using bracing system for various columns rigidity. The maximum efficiency occurred when using bracing in all stories with increasing in the columns rigidity in the load direction as shown in Model C3. 

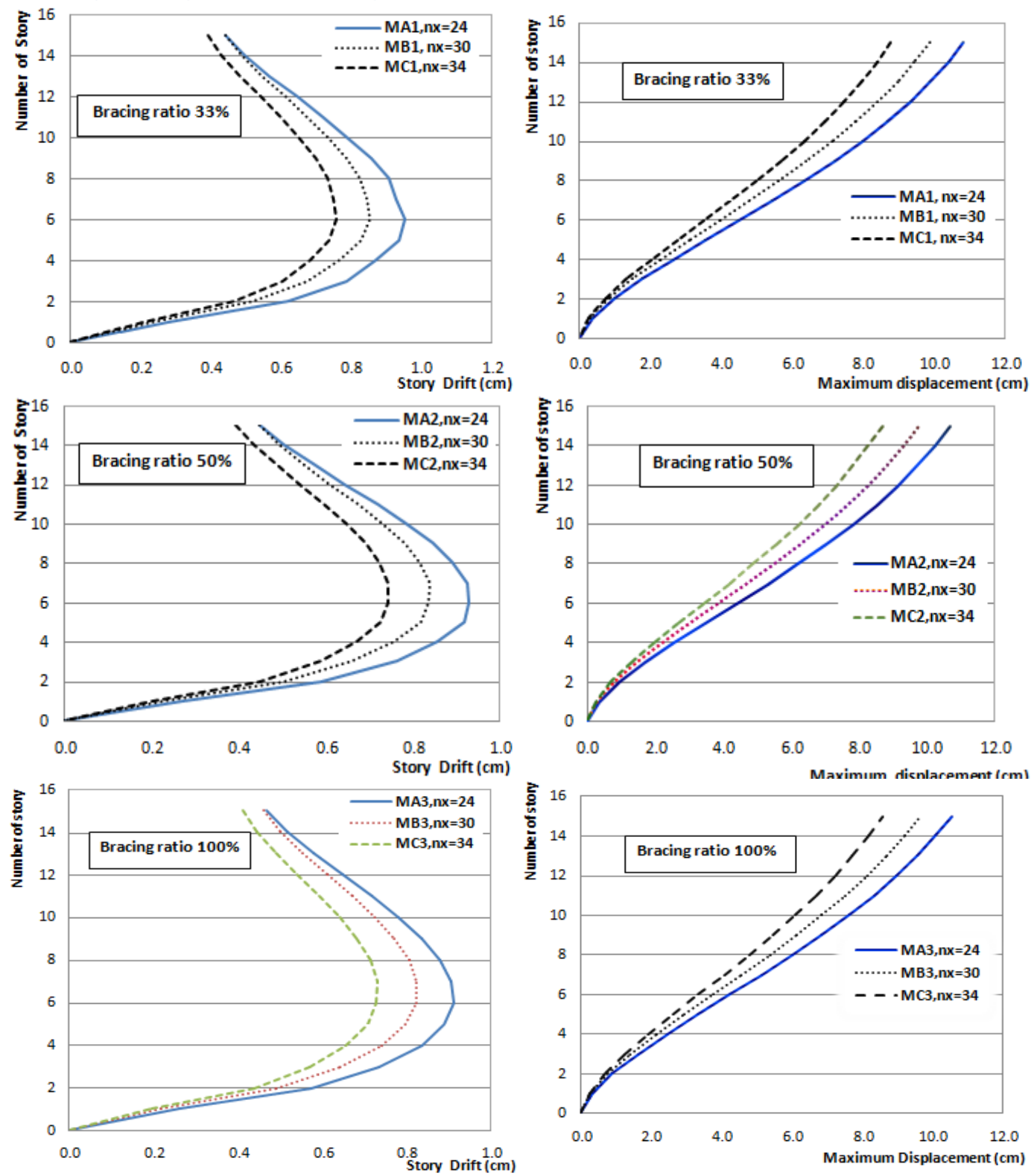

Fig. 12. Effect of bracing of various columns rigidity on top displacements and story drift models

\subsection{Effect of bracing for different beam cross- section}

In group $\mathrm{E}$ the main parameter was the beam -cross-section for $\mathrm{x}$ braced ratio $33 \%$ and the area of skylight used in this group is $(4 \times 15)$. The beam cross - section used in the $\mathrm{M}_{\mathrm{E} 0}$, $\mathrm{M}_{\mathrm{E} 1}$ is $25 \times 50$, in the $\mathrm{M}_{\mathrm{E} 2}$ is $25 \times 60$ and in the $\mathrm{M}_{\mathrm{E} 3}$ is $25 \times 70$. Model $\mathrm{E}_{0}$ was taken without any bracing. From Fig (13) it can be noted that, when using 33\% bracing ratio with increasing of the beam cross-section, the top displacement and maximum story drift decreased. The rate of decrease was larger as the beam dimension increased. The percentage of the reduction in story drift for Model $\mathrm{M}_{\mathrm{E} 3}$ compared with that of the un braced Model $\mathrm{M}_{\mathrm{EO}}$ was $48.2 \%$. The minimum bending moment occurred when using $33 \%$ bracing ratio with increase in beam cross -section. 
Table 2.

Building with $33 \%$ bracing ratio for various beam cross-section group

\begin{tabular}{|c|c|c|c|c|c|c|c|c|c|c|c|c|}
\hline$\stackrel{\Xi}{\Xi}$ & 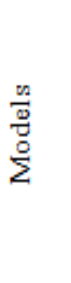 & $\begin{array}{l}\rightleftarrows \\
\rightleftarrows\end{array}$ & 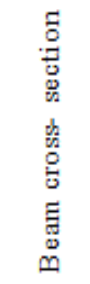 & 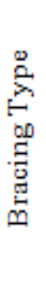 & 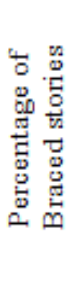 & $\underset{\infty}{\widehat{E}}$ & $\begin{array}{l}\vec{F} \\
\infty\end{array}$ & $\underset{\dot{0}}{\stackrel{\Xi}{0}}$ & $\begin{array}{l}\vec{z} \\
\dot{0} \\
\overline{8}\end{array}$ & 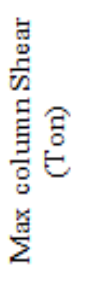 & 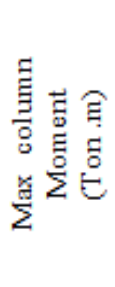 & 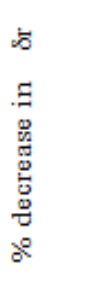 \\
\hline \multirow{4}{*}{$\mathrm{E}$} & $\mathrm{M}_{\mathrm{E} 0}$ & 24 & $25 \times 50$ & & - & 11.64 & 1.26 & 1.0335 & 1.206 & 16.82 & 131 & $\ldots$ \\
\hline & $\mathrm{M}_{E 1}$ & 24 & $25 \times 50$ & $\mathrm{P}$ & $33 \%$ & 10.6 & 1.15 & 0.9348 & 1.091 & 16.99 & 113.22 & $9.6 \%$ \\
\hline & $\mathrm{M}_{E 2}$ & 24 & $25 \times 60$ & $\mathrm{P}$ & $33 \%$ & 7.7 & 0.84 & 0.6924 & 0.808 & 17.74 & 97.58 & $33.0 \%$ \\
\hline & $\mathrm{M}_{\mathrm{E} 3}$ & 24 & $25 \times 70$ & $P$ & $33 \%$ & 5.9 & 0.64 & 0.5349 & 0.624 & 18.66 & 87.23 & $48.2 \%$ \\
\hline
\end{tabular}

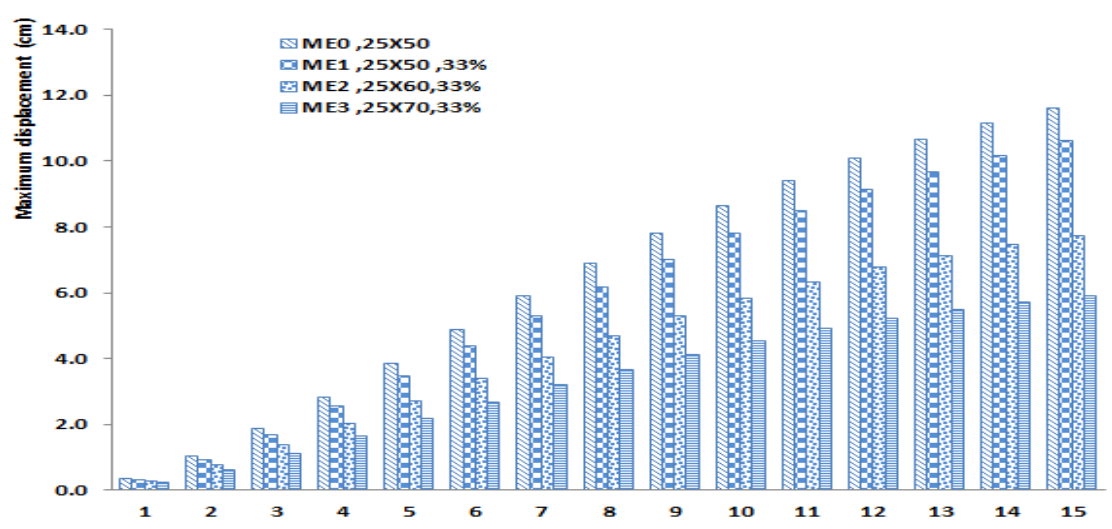

Fig. 13. Effect of bracing for various beam -cross-section for $33 \%$ bracing ratio on top displacements and story drifts model and contain.

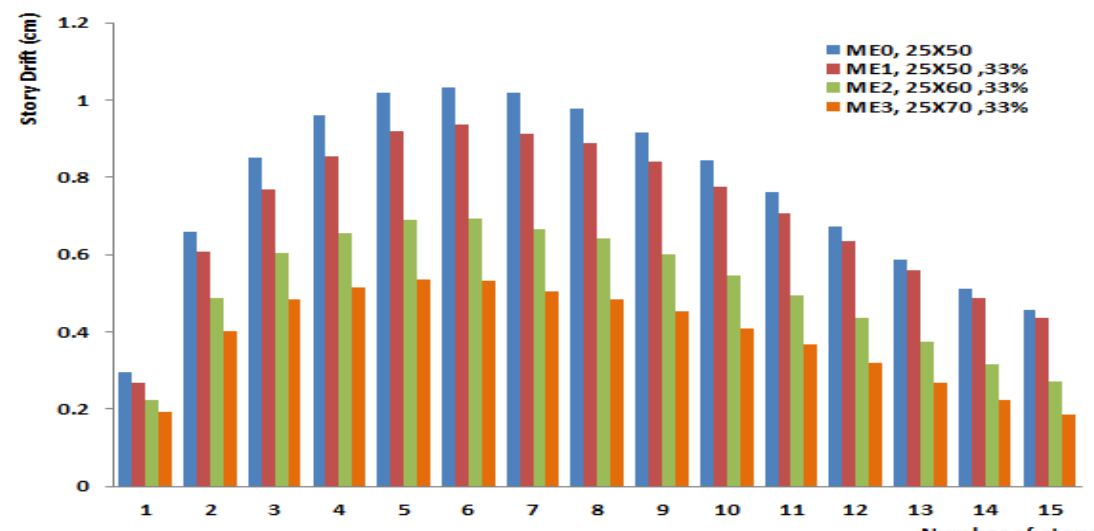

Fig. 13. Effect of bracing for various beam -cross-section for $33 \%$ bracing ratio on top displacements and story drifts model.

\section{Summary and conclusion}

In this study R.C bracing had been used to strengthen skylight columns of RC buildings for earthquake resistance. The analysis was done by equivalent static load (ESL), which was adopted on the Egyptian code for load and forces (ECLF2012). The main findings of the study can be summarized as follows: 
- The R.C bracing system with various columns rigidities in the load direction significantly reduced the top displacements, story drift as well as bending moment and shear force on columns. Using the R.C bracing bring the unsafe values of top displacement and story drift to be within the allowed values.

- The influence of bracing decreased as the ratio of braced stories decreased.

- The staggered plane bracing on two axes was more effective than the bracing in one axis for the same bracing ratio.

- The effect of bracing with increasing beam cross-section gives almost large decrease in top displacement, maximum story drift, maximum moment and maximum shear.

\section{REFRENCES}

[1] Antonio Di Cesare and Felice Carlo Ponzo,"Seismic Retrofit of Reinforced Concrete Frame Buildings with Hysteretic Bracing Systems :Design Procedure and Behaviour Factor", Hindawi :Shock and Vibration, 23 March 2017.

[2] Baran M ," Precast Concrete Panel Infill Walls for Seismic Strengthening of Reinforced Concrete Framed Strcutures ", PhD thesis, Middle East Technical University, Ankara, 2005.

[3] Computers and Structures, Inc (CSI), ETABS 2015 university Avenue Manuals (1998), Berkeley, California .

[4] ECLF2012's empirical expression for calculating the fundamental period of vibration gives almost the same fundamental period calculated from the structural model in case of flexible and rigid diaphragm. This means the change in diaphragm rigidity has no significant effect on the fundamental period of vibration.

[5] Egyptian code for Design and Construction the Reinforced Concrete Building (ECP 203-2007), 2007.

[6] Federal Emergency Management Agency, " Reinforce Building With Cross Bracing, Earthquake Handbook", FEMA Hazard Mitigation Handbook Series , 2002.

[7] G Navya, PankajAgarwal, "Seismic Retrofitting of Structures by Steel Bracings",ElSevier,ProcediaEngineering:www.elSevier.com/locate/Procedia Engineering 144 (2016) .

[8] Gorgulu, T., Tama, Y.S., Yilmaz, S., Kaplan, H., Ay, Z., "Strengthening of Reinforced Concrete Structures With External Steel Shear Walls ", Journal of Constructional Steel Research, doi:10.1016/j.jcsr.2011.08.010, 2011.

[9] Hossam S. Badawi and Sherif A. Mourad " Observations from the 12 October 1992 Dahshour earthquake in Egypt ", Natural Hazards journal, Vol. 10, No. 3, November, pp261-274 , 1994.

[10] Kaplan, H., Yılmaz, S., Cetinkaya, N., Nohutcu, H. and Atımtay, E. Gvnen, H, " A New Method for Strengthening of Precast Industrial Structures" , Journal of The Faculty of Engineering and Architecture of Gazi University, 24 No.4, 659-665, (in Turkish), 2009.

[11] Masri A. and Goel S,"Seismic design and testing of an RC slab-column frame strengthened with steel bracing " ,Earthquake Spectra, 12, No.4, 645-666,1996.

[12] Moehle J. P, "State of research on seismic retrofit of concrete building structures in the US" , Proceeding of US-Japan Symposium and Workshop on Seismic Retrofit of Concrete Structures - State of Research and Practice, USA, 2000.

[13] Naveen Kumar B.S $S^{1}$, Naveen B.S $S^{2}$, Parikshith Shetty ${ }^{3}$, " Time Period Analysis of Reinforced Concrete Building with and Without Influence of Steel Bracing", journal homepage: International Journal of Modern Chemistry and Applied Science 2015.

[14] Yılmaz, S., Kaplan, H., Tama, Y.S., Çalışkan ,Ö., Solak, A ; "Experimental program on design and application of external retrofit walls for low ductility RC frames" 4 th International Conference on Advances in Experimental Structural Engineering , Ispra, Italy,2011.

[15] Z.A. Siddiqi and Muhammad Ashraf, "Steel Structures", Help Civil Engineering Publisher Lahore, Pakistan, 2001. 
"تقوية أعمدة المناور في المباني لمقاومة الزلازل بأستخدام الثكلات "

$$
\text { الملخص العربي }
$$

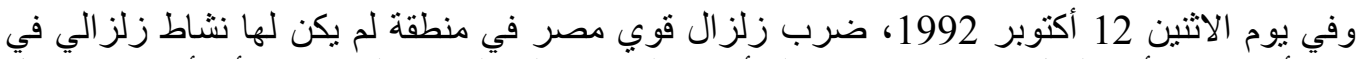

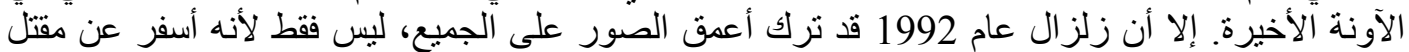

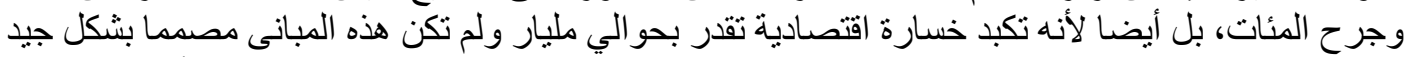

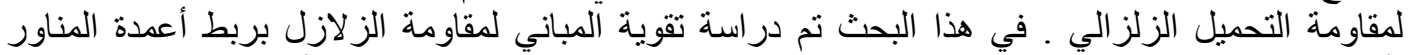

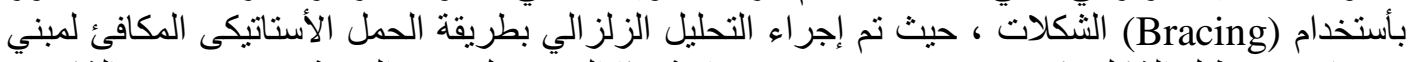

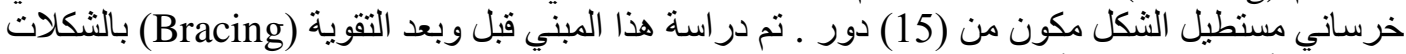

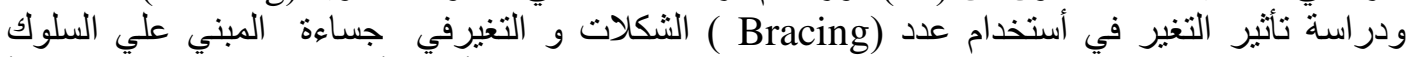

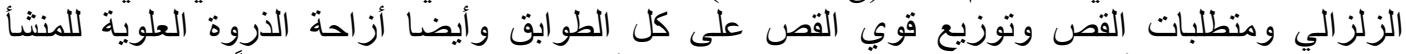

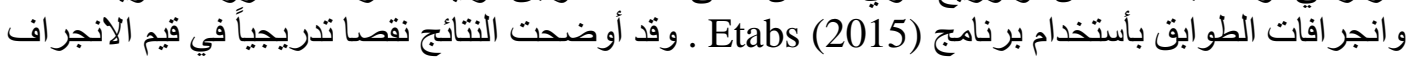

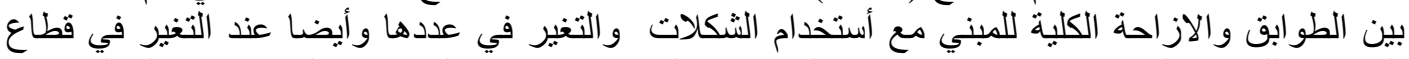

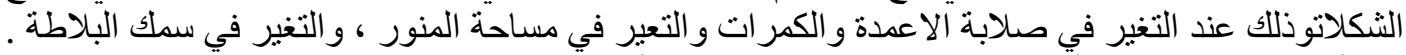

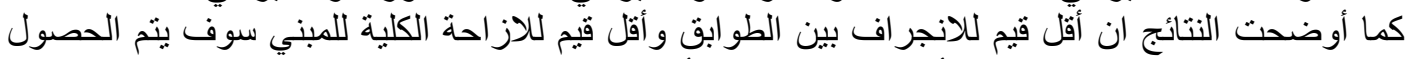

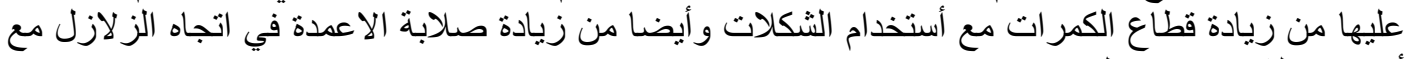

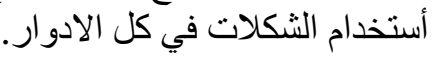

